Elsevier required licence: (C 2019. This manuscript version is made available under the CC-BYNC-ND 4.0 license http://creativecommons.org/licenses/by-nc-nd/4.0/

The definitive publisher version is available online at https://doi.org/10.1016/ j.scitotenv.2019.05.382 


\title{
Development of a water cycle management approach to Sponge City construction in Xi'an, China
}

D. Su ${ }^{\mathrm{a}}$, Q.H. Zhang, ${ }^{\mathrm{a}, \mathrm{b} *}$, H.H. Ngo ${ }^{\mathrm{c}}$, M. Dzakpasu ${ }^{\mathrm{d}}$, W.S. Guo ${ }^{\mathrm{c}}$, X.C. Wang ${ }^{\mathrm{a} * *}$

${ }^{\mathrm{a}}$ Key Lab of Northwest Water Resource, Environment and Ecology, Ministry of

Education, Xi' an University of Architecture and Technology, Xi'an 710055 China

${ }^{\mathrm{b}}$ International Science \& Technology Cooperation Center for Urban Alternative Water Resources Development, Xi'an 710055 China

${ }^{\mathrm{c}}$ Centre for Technology in Water and Wastewater, School of Civil and Environmental Engineering, University of Technology, Sydney, PO Box 123, NSW 2007, Australia

${ }^{\mathrm{d}}$ School of Environmental and Municipal Engineering, Xi'an University of Architecture and Technology, Xi' an 710055 China

Corresponding author: Qionghua Zhang

E-mail: qionghuazhang@gmail.com

Corresponding author:Xiaochang Wang

E-mail: xcwang@xauat.edu.cn

\begin{abstract}
:
In recent years, climate change, population growth, and inefficient use of water have exacerbated the water resources scarcity problems around the world. Hence, this paper establishes a new approach of Sponge City construction (SCC)based on water
\end{abstract}


cycle management (WCM)for the sustainable exploitation ofgroundwater, recycled wastewater and rainwater in the Xi' an Siyuan University. The Universityis located in an isolated area that is far away from the city center so that no centralized water supply system could be utilized. To mitigate water scarcity problems in the University, $39 \%$ of the annual rainfall is harvested and stored from impervious surfaces and grasslands by using the Curve Number $(\mathrm{CN})$ method. This stored water is reused for non-potable purposes: $40 \%$ for toilet flushing and $60 \%$ as miscellaneous water. According to findings, the available rainwater of $500-700 \mathrm{~m}^{3} / \mathrm{d}$ accounts for $16-23 \%$ of the non-potable water from April to December. Moreover, the utilization rate of water resources increases from $204 \%$ to $227 \%$. With the minimum volume of large-scale rainwater harvesting cistern of $52760 \mathrm{~m}^{3}$, the environment could be adequately watered while improving the expansion and development conditions on the campus. Furthermore, water scarcity problems could be mitigated through optimization of the water resources utilization system. This study demonstrates that this new approach of SCC based on WCM could alleviate water resources scarcity problems in Xi'an Siyuan University effectively. It is hoped that this study will provide a model and example of the new approachfor future applications.

\section{Keywords:}

Sponge City construction (SCC); Water cycle management (WCM); Rainwater harvesting; Water resources utilization; System optimization 


\section{Introduction}

The UN Comprehensive Assessment of the Fresh-water-Resources of the World estimated that approximately a third of the world's population was considered to suffer from water scarcity problems(Arnell, 2004). Moreover, two-thirds of the world's population would be living in water-deficient countries by 2025 (Arnell, 2004; Zhang, 2016). In addition, due to the differences in the spatial and temporal distribution of water resources, water scarcity problems (both of quality and quantity) are becoming increasingly prominent in many countries and regions, such as South and West Asia, Middle East and North Africa, Eastern Australia and Western United States ( Rasul, 2016; Cao et al., 2015; Fox et al., 2011; Bichai and Smeets, 2013; Philpot et al., 2016). More specifically, the per capita water availability in Northern China is as little as $1 / 25$ of the world average, so that this region experiences an extreme shortage of water resources (Guan and Hubacek, 2007;Zhang, 2016; Dou, 2018; Yan et al., 2018;).

Several theories and techniques have been proposed and applied in many countries to solve the water scarcity problems.Examples include Low Impact Development (LID) and Best Management Practices (BMPs) in the United States, Sustainable Urban Drainage Systems (SUDS) in the UK and Sponge City construction (SCC) in China (Baek et al., 2015; Sun et al., 2016; Loperfido et al., 2014; Tedoldi et al., 2016; Shao et al., 2016; Chan et al., 2018; Thuy et al., 2019; Li et al., 2019). These theories and techniques demonstrate that water scarcity problems 
could be alleviated by returning the land uses to natural state and harvesting rainwater. A common point can be summed up that water scarcity problems must be considered within the natural hydrological cycle if it is tobe solved. The natural hydrological cycle is not merely the circulation of water through the ocean, atmosphere, land, surface and subsurface water bodies, but also a process of water purification through natural processes. Thus,both the quantity and quality of renewable water resources could be secured simultaneously. (Bennett, 2008; Liu and Xia, 2012; Wang, 2015; Pokorný and Rejšková, 2008). Consequently, a conventional water resources utilization approach was formed, whereby the water resources in the upstream of a river is first used by humans and then discharged to the downstream after treatment. This approach was more than ideal when the world population was no more than 2 billion and natural resources were considered as plentiful for human consumption in an unrestricted manner.Duringthis period, this artificial water cycle causedminimal disturbances to the natural hydrological cycle (Feng et al., 2008). However, nowadays, with climate change and population growth, increased water consumption by human beings has significantly disturbed the natural hydrological cycle and led to severe shortage of water resources (Kundzewicz, 2008). Hence, this conventional water resources utilization approach also needs to change and reformed, at least in the near future, in order to maintain the characteristics of the natural hydrological cycle, as far as possible. Therefore, the concept of water cycle management (WCM), whichrefers to a multidisciplinary and multi-objective approach used to promote the sustainable exploitation of all available water resources in ways that best deliver multiple 
community objectives have been proposed. This presents a new approach to the design of urban water and wastewater systems by which freshwater supply and use, water reclamation and reuse, and the urban water environment are integrated into one water cycle(Gross et al., 2007; Ding et al., 2018).As a result, on the one hand, the efficiency of water resources utilization can increase.On the other hand, human disturbance on the natural hydrological cycle can significantly decrease because the quantity of water resources from upstream of the river, and that discharged into the downstream decrease. Therefore, combined with experiences from previous successful case studies(Wang et al., 2015), this approach of WCM is feasible and effective.

In China, the South-to-North Water Diversion Project, which is a large-scale water transfer project from Southern China to Northern China has partially solved the unequal distribution of water resources between the North and South (Zhao et al., 2015; Pohlner, 2016; Chen and Wang, 2012; Yan and Chen, 2013; Zhuang et al., 2019). However, finding long-term solutions to the water resources problems in the region remain very difficult.Consequently, China recently initiated the implementation of the concept of Sponge City and put forward a strategic plan for 30 cities (Juárez and Jiang, 2016; Wang et al., 2015; Liu et al., 2016; Qian, 2016; Qian, 2016). Sponge City is a concept closely relatedto WCM. Its purpose is to recycle rainwater and ensure the sustainable development of society and the environment, while also mitigating potential flood and water-related disasters (Karim et al., 2015; Mehrabadi et al., 2013; Mahmoud et al., 2014). Consequently,the concept of WCM is 
becoming increasingly important.

Therefore, in this study, a new approach of SCC based on WCM is considered. A pilot study in China is put forward to provide a new model and example with good promotion and application value. The case study area of Xi'an Siyuan University is located in Northern China.The university occupies an isolated area located on a mountain that is far away from the city center. Consequently, no centralized water supply system can be used. Therefore, groundwater and recycle wastewater is exploited to meet water demands. However, water resources utilization seems to remain very high,whereby the over-exploitation of groundwater has caused significant groundwater table declines.Expansion and development of the isolated area further exacerbate the stated problem. Therefore, SCC based on WCM for the sustainable utilization of groundwater, reclaimed wastewater and rainwater has beenproposed for this region. The specific objectives of the study were to: (1) determine the maximum potential of rainwater harvesting (surface runoff) by using the Curve Number $(\mathrm{CN})$ method; (2) establish the approach of SCC based on WCM; (3) optimize the utilization of water resources in Xi'an Siyuan University. By this concept, water scarcity problems could be improved. Also, this new approach could provide some new ideas and good suggestions for the development and utilization of water resources in the future.

\section{Materials and methods}

\subsection{Study area and data collection}


This study was conducted in Xi'an Siyuan University, which is an isolated area, located in Xi'an, Shaanxi Province, China(E107 $40^{\prime} \sim 109^{\circ} 49^{\prime}$ and N33 $\left.39^{\circ} \sim 34^{\circ} 45^{\prime}\right)$. Xi'an Siyuan University occupies an area of $0.8 \mathrm{~km}^{2}$ and consists of buildings, impervious roads, green spaces and water spaces (Fig.1). Land uses include $60 \%$ of grasslands with good condition and $40 \%$ of impervious surfaces. This campus is situated on widely distributed sandy loam soil and light loam soil, which have high permeability and low potential runoff. There is an artificial lake on the campus, with an area of $3100 \mathrm{~m}^{2}$ and an effective water depth of $0.6 \mathrm{~m}$. There is a population of 25000 , and the potable water demand is $80-120 \mathrm{~L} /$ person $d$ on the campus. The types and volumes of water resources utilization are shown in Table 1.

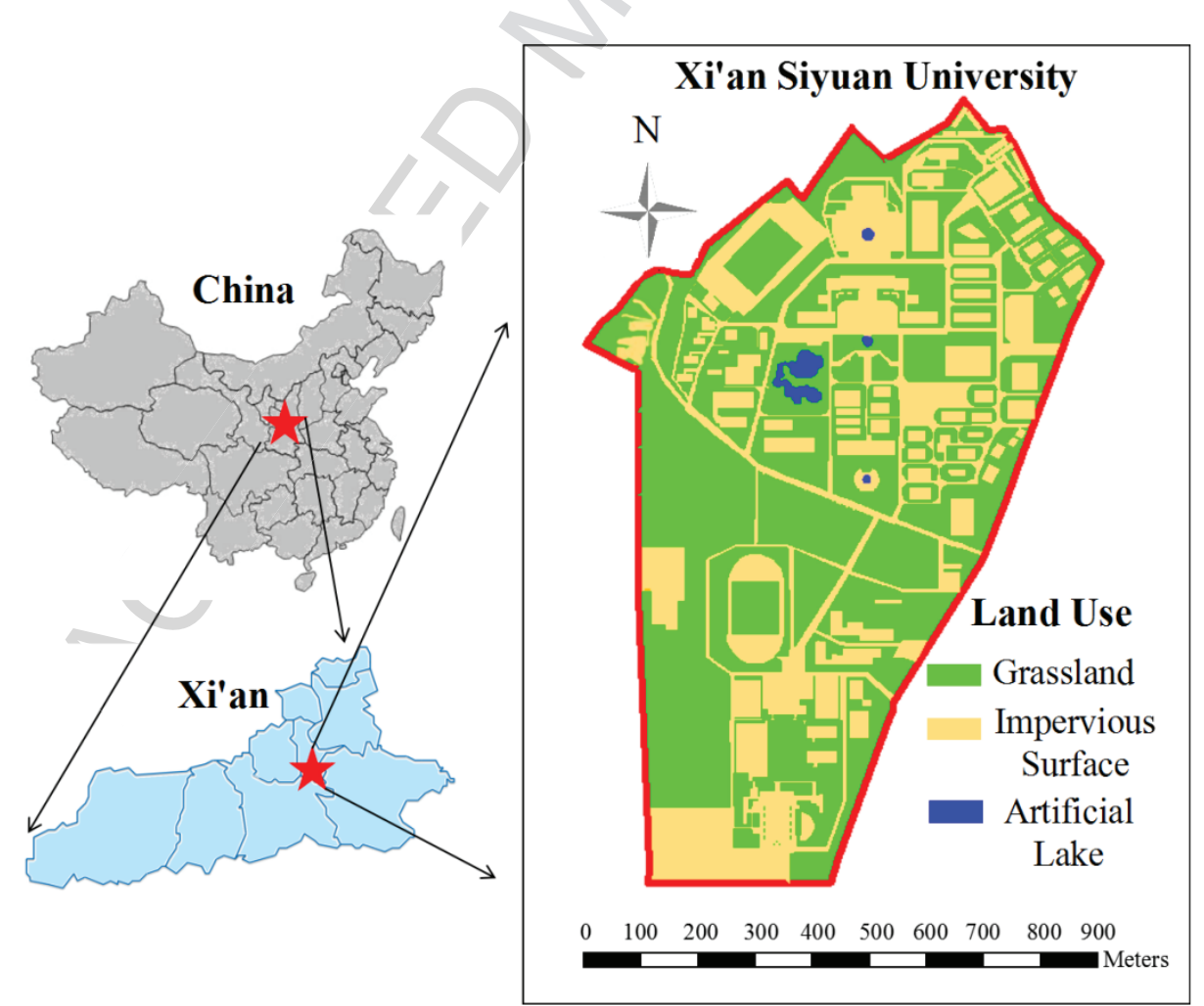

Fig. 1.Location and land use map of Xi'an Siyuan University in China. 
Table 1

Types and volumes of water resources utilization in Xi'an Siyuan University.

\begin{tabular}{llc}
\hline Water resources utilization & Type & Volume $\left(\mathbf{m}^{\mathbf{3}} / \mathbf{d}\right)$ \\
\hline Potable water use & Potable water & 3000 \\
& Toilet flushing water & 1200 \\
Non-potable water use & Miscellaneous water & 1800 \\
& Supplemental artificial lake water & 109 \\
\hline
\end{tabular}

With a temperate continental climate, Xi' an has an averagetemperature of $14.9^{\circ} \mathrm{C}$ an average wind speed of $1.8 \mathrm{~m} / \mathrm{s}$, an average annual rainfall of $545 \mathrm{~mm}$ and an average annual evaporation of $990 \mathrm{~mm}(\mathrm{Jia}$ et al., 2016). The rainy season is between May and October, which accounts for $80 \%$ of the annual rainfall. This study uses published data of monthly precipitation between 1993 and 2015 in Xi'an from China Statistical Yearbook (http://www.stats.gov.cn/tjsj/ndsj/) (Fig. 2). 

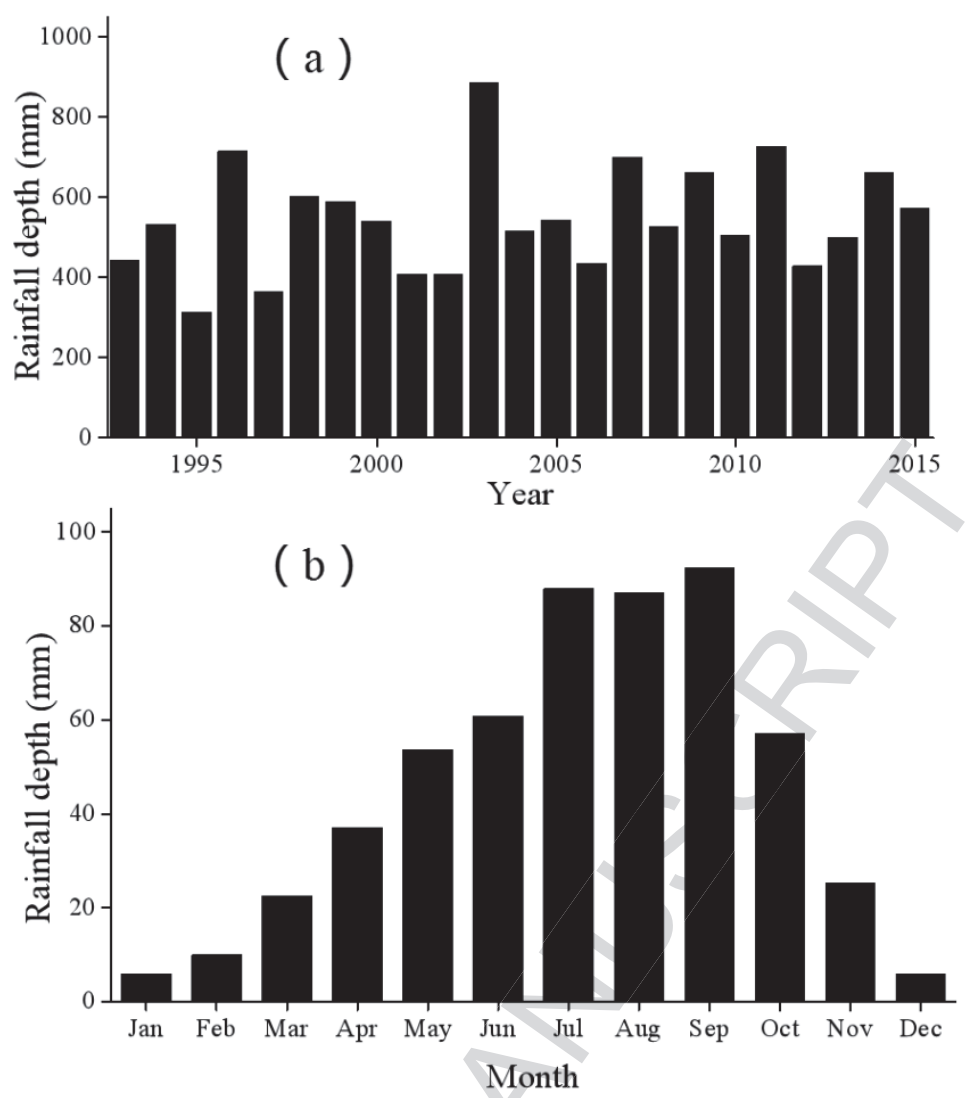

Fig. 2. (a) annual precipitation between 1993 and 2015 in Xi' an, (b) average monthly precipitation between 1993 and 2015 in Xi'an.

\subsection{Methodology}

\subsubsection{Curve Number method}

According to the theory of Sponge City, rainwater is an important non-conventional water resource, especially in the isolated area, so it can be harvested for reuse to mitigate water shortage problems. The potential of rainwater harvesting

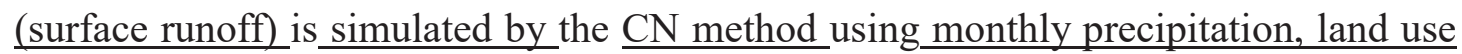
and hydrologic soil group in the Storm Water Management Model (SWMM) and the Long-Term Hydrologic Impact Assessment-Low Impact Development (L-THIA-LID) model(Ahiablame et al., 2013)._However, even a little change in the monthly 
precipitation, land use or hydrologic soil group could cause a large variation in the potentiality of rainwater harvesting because the relationship is not linear between the monthly precipitation, $\mathrm{CN}$ and harvested rainwater. The $\mathrm{CN}$ method is a simple procedure, which was developed empirically to simulate the potentiality of rainwater harvesting in a given region, and the steps involved are listed as follows:

1) Step 1: selecting the $C N$ according to different land uses and hydrologic soil group,

2) Step2: calculating the potential maximum retention $(S)(\mathrm{mm} / \mathrm{month})$ according to the selected $C N$,

$$
S=25400 / C N-254
$$

3) Step 3: calculating the initial abstraction $\left(I_{a}\right)$ ( $\mathrm{mm} / \mathrm{month}$ ), which includes interception, infiltration, surface storage and evaporation according to potential maximum retention $(S)(\mathrm{mm} / \mathrm{month})$,

$$
I_{a}=0.2 \cdot S
$$

4) Step 4: calculating the potentiality of rainwater harvesting $(Q)(\mathrm{mm} / \mathrm{month})$ according to potential maximum retention $(S)(\mathrm{mm} / \mathrm{month})$, initial abstraction $\left(I_{a}\right)$ (mm/month) and monthly precipitation $(P)(\mathrm{mm} / \mathrm{month})$.

$$
\begin{aligned}
& Q=\left[\left(P-I_{a}\right)^{2}\right] /\left[\left(P-I_{a}\right)+S\right] \text { for } P>I_{a} \\
& Q=0 \text { for } P \leq I_{a}
\end{aligned}
$$

\subsubsection{Water balance}

In order to fully meet all water demands and realize the target of zero dischargeof water resources in the isolated area, wastewater reuse is necessary. 
Reclaimed wastewater is suppliedfor various types of non-recoverable water uses. The water balance of water resources utilization in the isolated area is listed as follows:

$$
\sum_{\mathrm{i}=1}^{\mathrm{n}} Q_{\mathrm{Si}}=\sum_{\mathrm{j}=1}^{\mathrm{m}} Q_{\mathrm{NRj}}+\sum_{\mathrm{k}=1}^{\mathrm{s}} Q_{\mathrm{Lk}}
$$

where $Q_{\mathrm{Si}}$ is various types of water supply and $\mathrm{i}$ is from 1 to $\mathrm{n}, Q_{\mathrm{NRj}}$ is various non-recoverable water and $\mathrm{j}$ is from 1 to $\mathrm{m}$ and $Q_{\mathrm{Lk}}$ is various losing water and $\mathrm{k}$ is from 1 to $\mathrm{s}$.

\subsubsection{Efficiency analysis}

The efficiency of water resources utilization is related to wastewater reuse, and the goal of wastewater reuse is always to meet the demand of non-drinking water, so the efficiency of water resources utilization can be affected by non-potable water. Equation (6) is the efficiency of water resources utilization in the isolated area.

$$
\eta=\left(\sum_{i=1}^{n} Q_{S i}+\sum_{t=1}^{p} Q_{N P t}\right) / \sum_{i=1}^{n} Q_{S i}
$$

where $Q_{\mathrm{NPt}}$ is various non-potable water and $\mathrm{t}$ is from 1 to $\mathrm{p}$.

\subsubsection{Optimization processes}

In order to mitigate the water scarcity problems, the water balance and efficiency of water resources utilization system in the isolated area need to be further optimized by establishing a new paradigm of SCC based on WCM. Fig. 3 shows the optimization processes of water resources utilization system in the isolated area. 


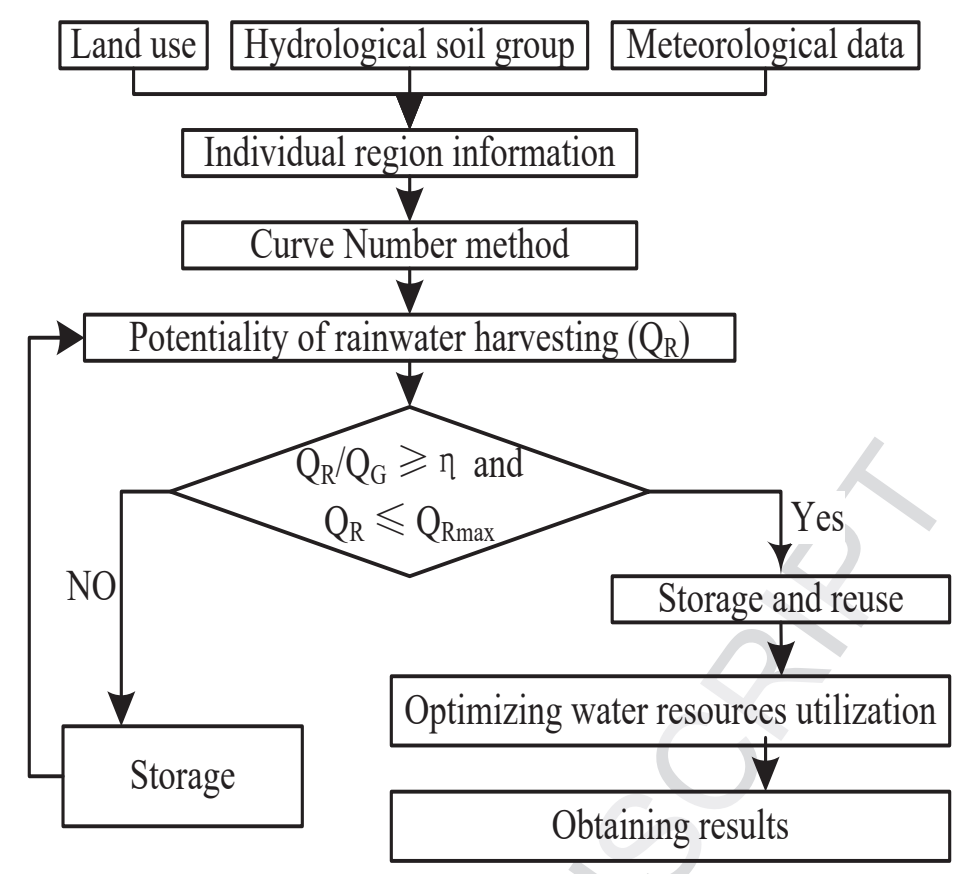

Fig. 3. Optimization processes of water resources utilization system in the isolated area according to Sponge City construction based on water cycle management.

Note: $\mathrm{Q}_{\mathrm{R}}$ is the monthly potentiality of rainwater harvesting; $\mathrm{Q}_{\mathrm{G}}$ is the quantity of non-potable water; $\eta$ is the ratio of $\mathrm{Q}_{\mathrm{R}}$ and $\mathrm{Q}_{\mathrm{G}}$ (determined according to the actual situation); $\mathrm{Q}_{\mathrm{Rmax}}$ is the maximum $\mathrm{Q}_{\mathrm{R}}$ which can be reused in the water resources utilization (determined according to the capacity of wastewater treatment plant).

\section{Results and discussion}

\subsection{Potentiality of rainwater harvesting}

\subsubsection{Impervious surface analysis}

A CN of 98 was obtained for impervious surfaces and the hydrological soil group of B. Therefore, the potentiality of rainwater harvesting was calculated by using Equations (1), (2), (3) and the monthly precipitation shown in Fig. 2. Fig. 4 illustrates 
the monthly potentiality of rainwater harvesting in Xi'anSiyuan University. According to the findings, monthly collectable rainwater quantities increases steadily up to a maximum in the middle of the yearin July, August, and September, and then declinesrapidly during the rest of the year (Fig. 4).

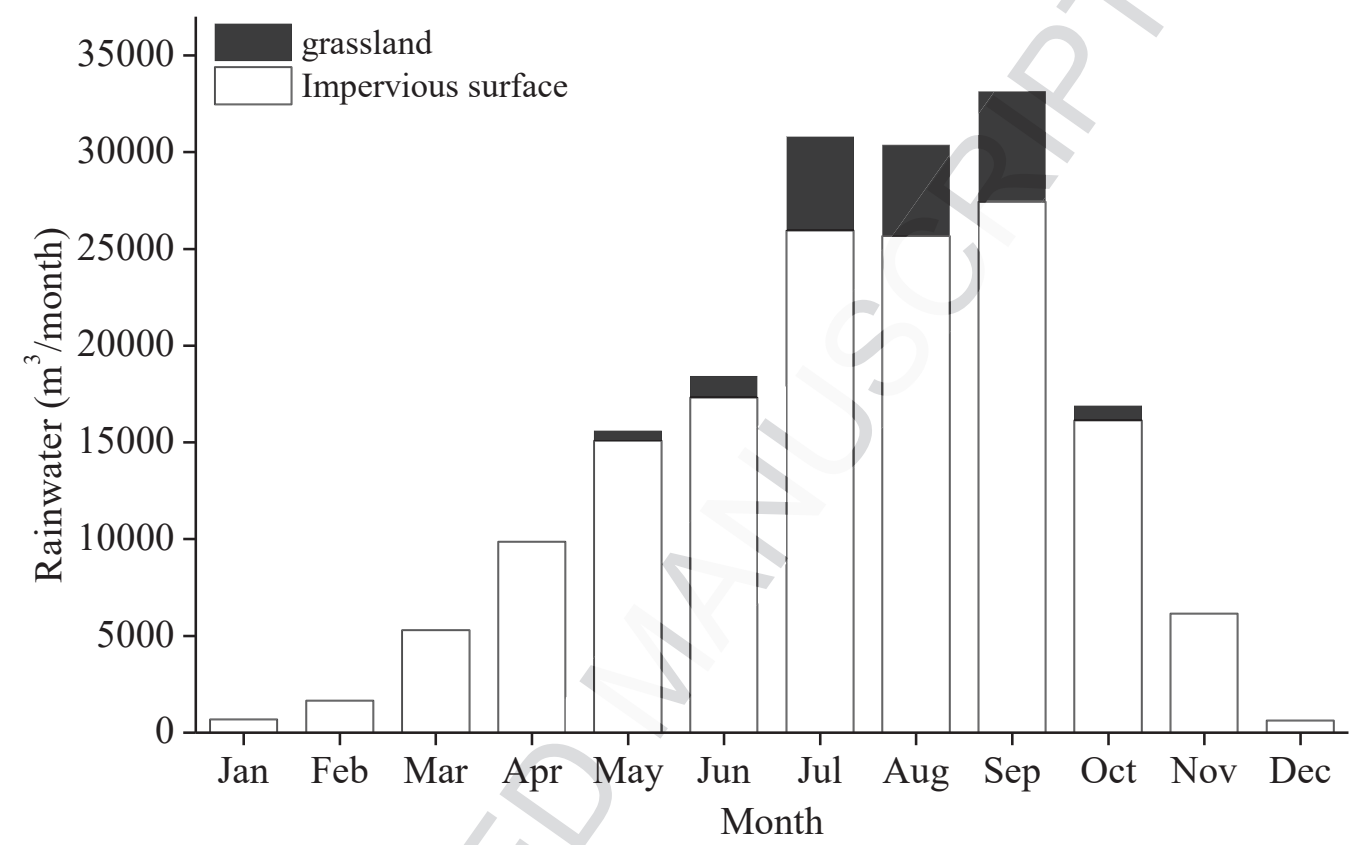

Fig. 4. The monthly potentiality of rainwater harvesting (impervious surface and grassland) in Xi'an Siyuan

University.

\subsubsection{Grassland analysis}

A $\mathrm{CN}$ of 61 for the land use of grassland with good condition and the hydrological soil group of B.The monthly potentiality of rainwater harvesting for grasslandsare presented in Fig. 4. For this land use type, the maximum monthly collectable rainwater quantitieswere also recorded in July, August, and September.In the other months, values were almost zero. 
Fig. 4 demonstrates that the total harvestable rainwater amounts to $39 \%$ of the total annual rainfall in the isolated area. Furthermore, grassland areasshowed higher infiltration capacities compared to impervious surfaces, whereby the impervious surfaces tend to produce large surface runoff. Nonetheless, surface runoff would be generated on the grasslands when precipitation was greater than the infiltration capacity, for example, in July, August, and September.

\subsection{Integrated water cycle management}

\subsubsection{Rainwater reuse}

According to section $2.1,3000 \mathrm{~m}^{3} / \mathrm{d}$ of groundwater has been exploited, and wastewater has also been reused in order to meet the demand for potable and non-potable water. However, water use remains intense in the isolated area. Therefore, rainwater (surface runoff) from the impervious surfaces and grasslandsis proposed to be harvested. Collected rainwater may bestored firstly in cisterns, and then, treated in the wastewater treatment plant for non-potable reuse (see Fig. 5). Storage and treatment would guarantee the quality of harvested rainwater(Wang et al., 2017).. 


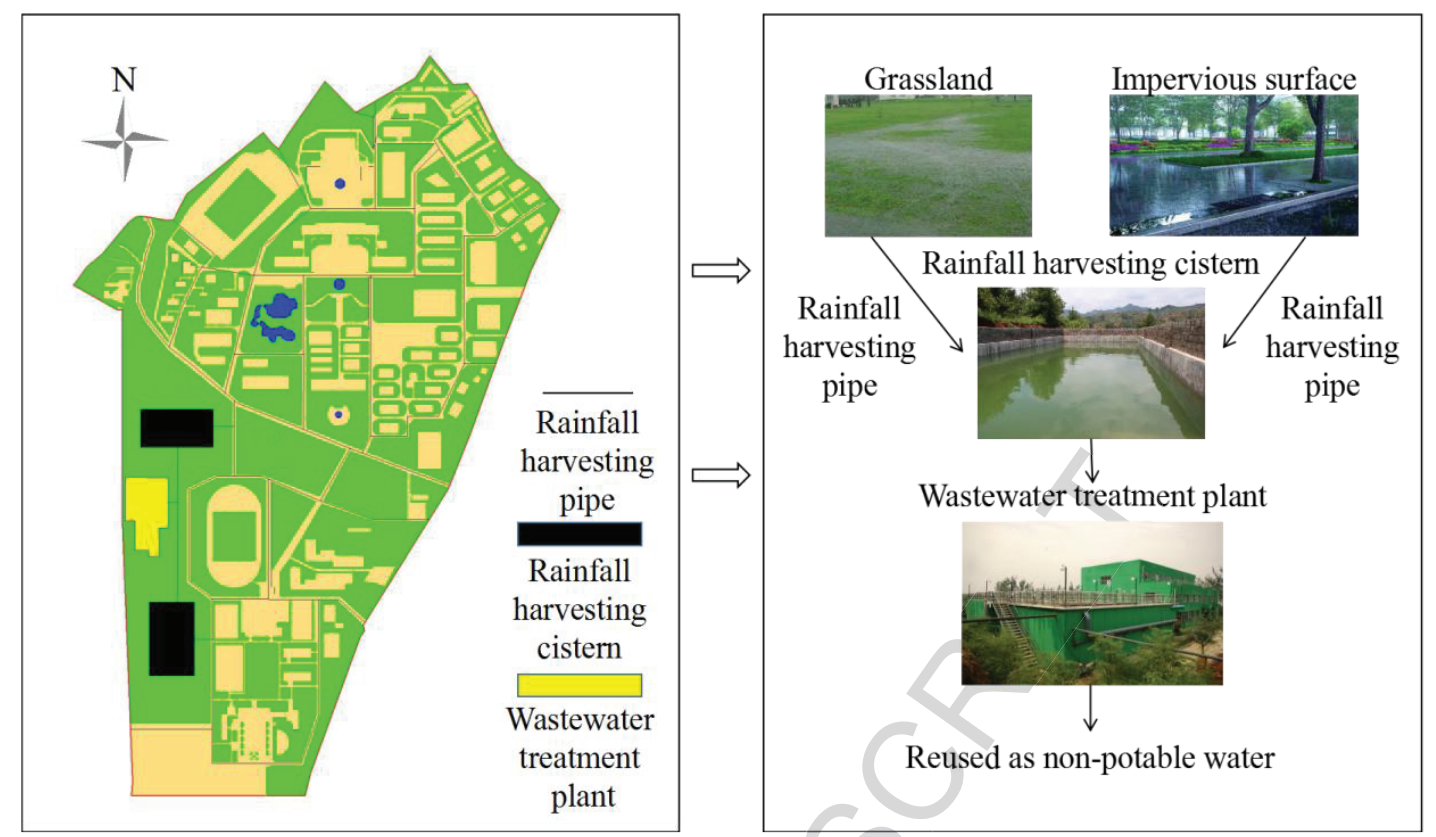

Fig.5.Schematic diagram of rainwater reuse in Xi' an Siyuan University.

\subsubsection{Water resources utilization system optimization}

Fig. 6 shows how the exploitation of groundwater and recycle wastewater in Xi'an Siyuan University helped meet the total water demand.A final residual water of $23 \mathrm{~m}^{3} / \mathrm{d}$ is obtained after the reclamation of sewage, which demonstrates a nearly zero discharge rate for the water resources utilization. Moreover, the reuse of wastewater met the demand for non-potable water and the rate of water resources utilization increased by up to $204 \%$.

The introduction of rainwater harvesting into the water resources utilization system changed the utilization rate of non-potable water (see Fig. 6). About $40 \%$ of the rainwater would be used for toilet flushing, and $60 \%$ for miscellaneous water. However, for the effective recycling of rainwater, the ratio of rainwater reuse and non-potable water is required to be greater than $15 \%$. On the other hand, based on the capacity of the wastewater treatment plant, the maximum quantity of treatable 
rainwater is less than $700 \mathrm{~m}^{3} / \mathrm{d}$. Therefore, an optimal rainwater reuse scheme could be obtained by minimizing the volume of rainwater harvesting cisterns (see Fig. 7).

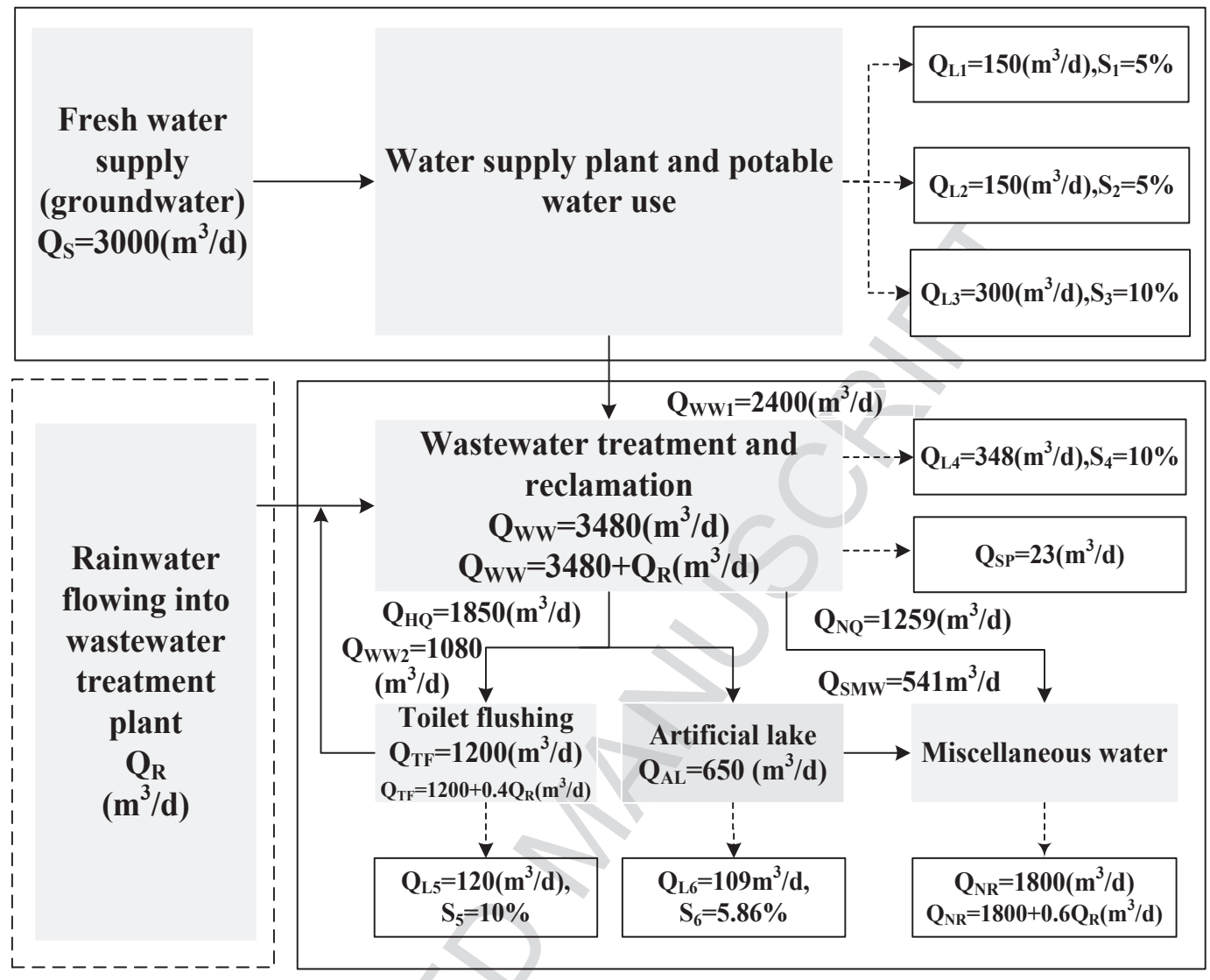

Fig. 6. Water balance and collectable rainwater quantity utilization approach of rainwater and wastewater

resources utilization system in Xi'an Siyuan University.

Note: a detailed description of symbols and abbreviationsused in the water resources utilization system are listed in the appendix. 


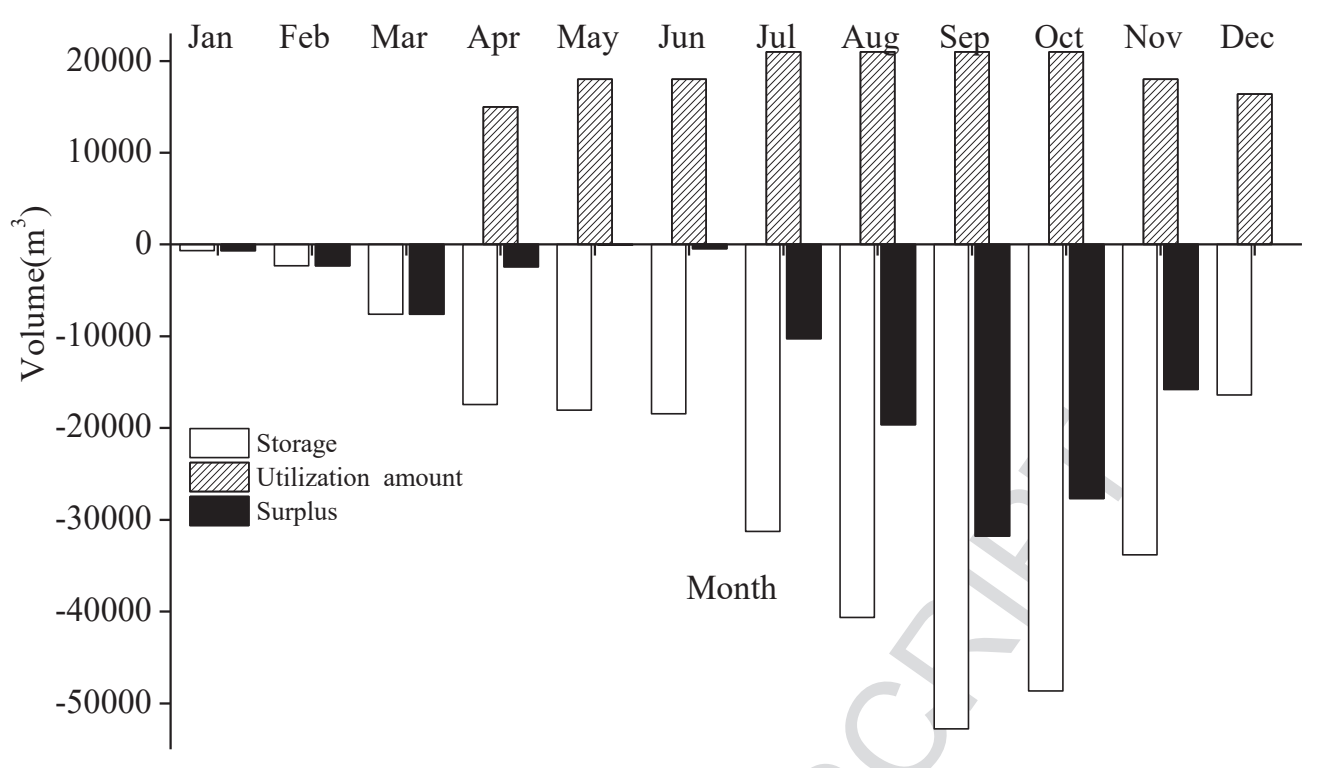

Fig. 7. Volume of rainwater storage and utilization in Xi'an Siyuan University.

Fig. 7 shows that the available rainwater in January, February, and March may not be enough to meet the $15 \%$ minimum ratio of available rainwater and non-potable water.So, this rainwater would be stored until April. From April to December, the rainwater that was stored in the cisterns would be reused. The available rainwater, ratio of available rainwater and non-potable water and utilization rate of water resources are summarized in Table 2. The available rainwater is shown to range from 500 to $700 \mathrm{~m}^{3} / \mathrm{d}$. The ratio of available rainwater and non-potable water is between $16 \%$ and $23 \%$ and utilization rate could increase from $204 \%$ to $227 \%$. Therefore, the volume of cisterns requiredis at least $52760 \mathrm{~m}^{3}$. 
Table 2

Overview ofrainwater recycling in Xi' an Siyuan University.

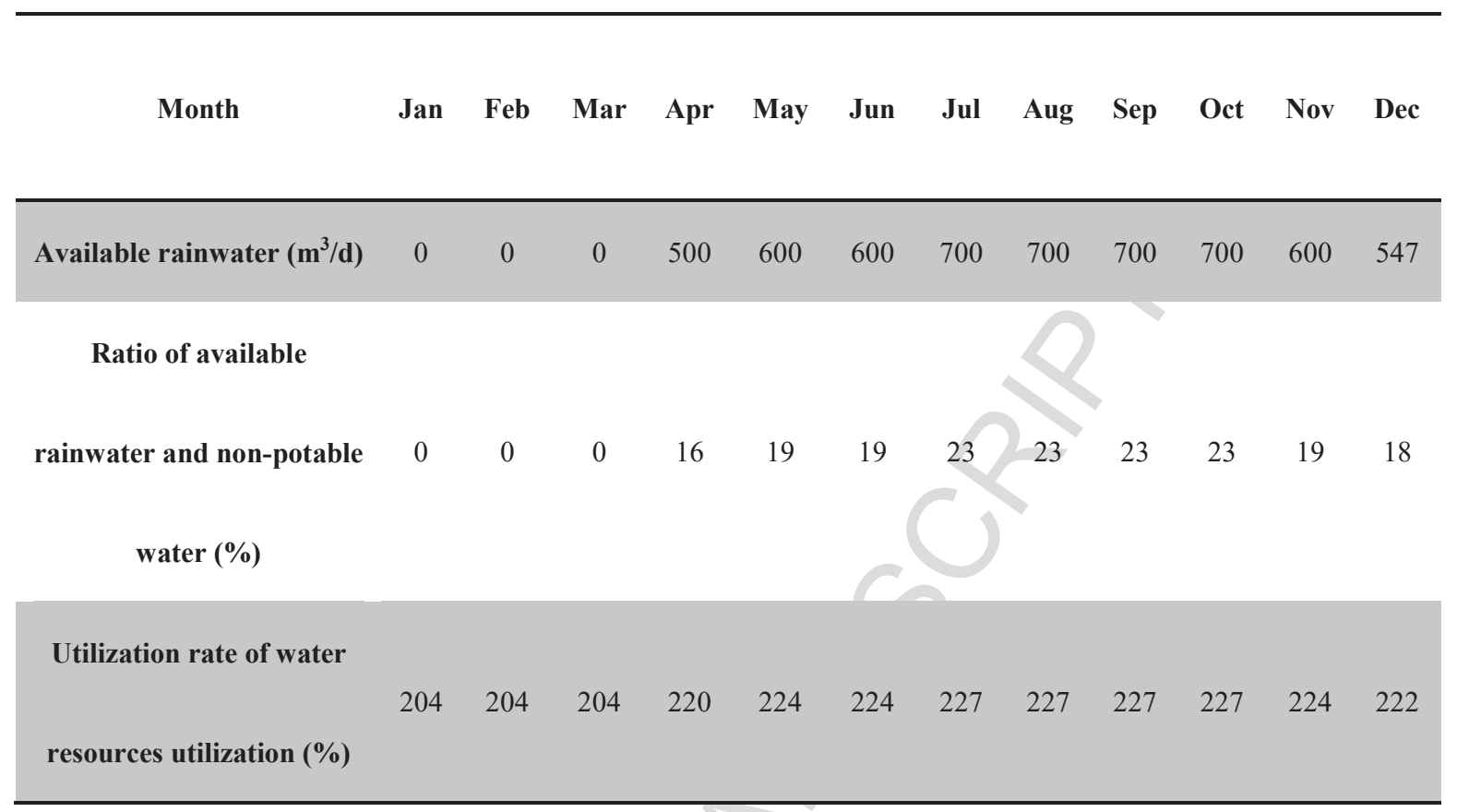

Thus, the water resources utilization system could be further optimized by this paradigm of SCC encompassing groundwater use, wastewater reuse and rainwater reuse based on the concept of WCM. By this development, the water scarcity problems in Xi'an Siyuan University could be mitigated and the environmental quality could be further improved. Moreover, it could provide some good ideas and suggestion for further expansion and development. Overall, the results suggest that this new integrated WCM concept could mitigate the water scarcity problems, especially for groundwater in the isolated area.

Furthermore, these results demonstrate that rainwater could be fully reused to mitigate groundwater scarcity problem from April to December. So, it is feasible and effective to use rainwater to mitigate water resources scarcity problems based on 
WCM.

\section{Conclusions}

In this paper, a new integrated WCM approach of SCC encompassing groundwater use, wastewater reuse, and rainwater reuse has been established based on WCM to mitigate water scarcity problems, especially for groundwater shortage problems in an isolated area. The potentiality of rainwater harvesting in Xi'an Siyuan University was calculated by using the $\mathrm{CN}$ method. Overall, this study demonstrates that the reuse of rainwater can further optimize the water resources utilization system in the isolated area. In turn, the environment quality of Xi'an Siyuan University can be further improved. Of course, it contributes to the expansion and development of the isolated area. Nonetheless, the economic situations and ecological conditions need to be further studied in further detail. It is hoped that this approach of SCC based on the concept of WCM proposed in this paper could provide some new ideas and good suggestions, and of course, be used as a model and example for the development of water resources utilization in the future, especially in developing countries experiencing serious water scarcity problems. 
Appendix: Symbols and meanings of the water resources utilization system in Fig. 6.

\begin{tabular}{|c|c|}
\hline Symbol & Meaning \\
\hline$Q_{S}$ & Quantity of supply water. \\
\hline $\mathrm{Q}_{\mathrm{L} 1}$ & Loss water during the treatment of the supply water plant. \\
\hline $\mathrm{S}_{1}$ & Loss rate of the supply water plant, $5 \%$. \\
\hline $\mathrm{Q}_{\mathrm{L} 2}$ & Loss water during the process of drinking. \\
\hline $\mathrm{S}_{2}$ & Loss rate during the process of drinking, $5 \%$. \\
\hline $\mathrm{Q}_{\mathrm{L} 3}$ & Loss water from the supply water plant to the wastewater treatment plant. \\
\hline $\mathrm{S}_{3}$ & Loss rate from the supply water plant to the wastewater treatment plant, $10 \%$. \\
\hline$Q_{W W 1}$ & Wastewater from the potable water use. \\
\hline $\mathrm{Q}_{\mathrm{ww}}$ & Wastewater in the wastewater treatment plant. \\
\hline $\mathrm{Q}_{\mathrm{L} 4}$ & Loss water during the treatment of the wastewater treatment plant. \\
\hline $\mathrm{S}_{4}$ & Loss rate of the wastewater treatment plant, $10 \%$. \\
\hline $\mathrm{Q}_{\mathrm{HQ}}$ & Quantity of the high quality treatment. \\
\hline $\mathrm{Q}_{\mathrm{NQ}}$ & Quantity of the normal quality treatment. \\
\hline $\mathrm{Q}_{\mathrm{SP}}$ & Final surplus water in the system. \\
\hline $\mathrm{Q}_{\mathrm{TF}}$ & Quantity of toilet flushing. \\
\hline $\mathrm{Q}_{\mathrm{L} 5}$ & Loss water during the toilet flushing. \\
\hline $\mathrm{S}_{5}$ & Loss rate during the toilet flushing, $10 \%$. \\
\hline Qww2 & Wastewater from the toilet flushing. \\
\hline $\mathrm{Q}_{\text {SMW }}$ & Miscellaneous water from the artificial lake. \\
\hline $\mathrm{Q}_{\mathrm{AL}}$ & High quality water flowing into the artificial lake. \\
\hline
\end{tabular}




\section{References}

Ahiablame, L.M., Engel, B.A., Chaubey, I., 2013. Effectiveness of low impact development practices in two urbanized watersheds: Retrofitting with rain barrel/cistern and porous pavement. J. Environ. Manage. 119, 151-161.https://doi.org/10.1016/j.jenvman.2013.01.019

Arnell, N.W., 2004. Climate change and global water resources: SRES emissions and socio-economic scenarios. Global. Environ. Change. 14 (1), 31-52.https://doi.org/10.1016/j.gloenvcha.2003.10.006

Baek, S.S., Choi, D.H., Jung, J.W., Lee, H.J., Lee, H., Yoon, K.S., Cho, K.H., 2015. Optimizing low impact development (LID) for stormwater runoff treatment in urban area, Korea: Experimental and modeling approach. Water. Res. 86, 122-131.https://doi.org/10.1016/j.watres.2015.08.038

Bennett, A., 2008. The water cycle: Managing long term sustainable water use. Filtr. Separat. 45, 12-15.https://doi.org/10.1016/S0015-1882(08)70329-X

Bichai, F., Smeets, P.W.M.H., 2013. Using QMRA-based regulation as a water quality management tool in the water security challenge: Experience from the Netherlands and Australia. Water. Res. 47 (20), 7315-7326.https://doi.org/10.1016/j.watres.2013.09.062

Cao, H., Amiraslani, F., Liu, J., Zhou, N., 2015. Identification of dust storm source areas in West Asia using multiple environmental datasets. Sci. Total. Environ. 502, 224-235.https://doi.org/10.1016/j.scitotenv.2014.09.025

Chan, F.K.S., Griffiths,J.A., Higgitt, D., Xu, S.Y., Zhu, F.F., Tang, Y.T., Xu, Y.Y., Throne, C.R., 2018. "Sponge City" in China-A breakthrough of planning and flood risk management in the urban context. Land Use Policy. 76, 772-778.https://doi.org/10.1016/j.landusepol.2018.03.005 
Chen, Z.S., Wang, H.M., 2012. Optimization and coordination of South-to North Water Diversion supply chain with strategic customer behavior. Water Science and Engineering. 5 (4), 464-477.https://doi.org/10.3882/j.issn.1674-2370.2012.04.010

Ding, A., Wang, J.L., Lin, D.C., Zeng, R., Yu, S.P., Gan, Z.D., Ren, N.Q., Li, G.B., Liang, H., 2018. Effects of GAC layer on the performance of gravity-driven membrane filtration (GDM) $\begin{array}{llll}\text { system for } & \text { rainwater }\end{array}$ 253-261.https://doi.org/10.1016/j.chemosphere.2017.10.034

Dou, X.S., 2018.China's inter-basin water management in the context of regional water shortage. Sustain. Water Resour. Manag. 4, 519-526. https://doi.org/10.1007/s40899-017-0134-3

Feng, L.H., Zhang, X.C., Luo, G.Y., 2008. Application of system dynamics in analyzing the carrying capacity of water resources in Yiwu City, China. Math. Comput. Simul. 79 (3), 269-278.https://doi.org/10.1016/j.matcom.2007.11.018

Fox, D., James, A., MclLvaine, B., 2011. Middle East boosts pump demand. World. Pumps. 2011 (1), 32-36.https://doi.org/10.1016/S0262-1762(11)70034-7

Gross, A., Shmueli, O., Ronen, Z., Raveh, E., 2007. Recycled vertical flow constructed wetland (RVFCW) -a novel method of recycling greywater for irrigation in small communities and households. Chemosphere. 66 916-923.https://doi.org/10.1016/j.chemosphere.2006.06.006

Guan, D.B., Hubacek, K., 2007. Assessment of regional trade and virtual water flows in China. Ecol. Econ. 61 (1), 159-170.https://doi.org/10.1016/j.ecolecon.2006.02.022 Jia, Z., Tang, S., Luo, W., Li, S., Zhou, M., 2016. Small scale green infrastructure design to meet 
different urban hydrological criteria. J. Environ. Manage. 171, 92-100.https://doi.org/10.1016/j.jenvman.2016.01.016

Juárez, E.I.A.Y., Jiang, Z.G., 2016. Flood exposure for vertebrates in China’s terrestrial priority areas for biodiversity conservation: Identifying internal refugia. Biol.Conserv. 199, 137-145.https://doi.org/10.1016/j.biocon.2016.04.021

Karim, M.R., Bashar, M.Z.I., Imteaz, M.A., 2015. Reliability and economic analysis of urban rainwater harvesting in a megacity in Bangladesh. Resour.Conserv.Recy. 104 (Part A), 61-67.https://doi.org/10.1016/j.resconrec.2015.09.010

Kundzewicz, Z.W., 2008. Climate change impacts on the hydrological cycle. Ecohydrol. Hydrobiol. 8 (2-4), 195-203.https://doi.org/10.2478/v10104-009-0015-y

Li, Q., Wang, F., Yu, Y., Huang, Z.C., Li, M.T., Guan, Y.T., 2019. Comprehensive performance evaluation of LID practices for the sponge city construction: A case study in Guangxi, China. Journal of Environmental Management. 231, 10-20. https://doi.org/10.1016/j.jenvman.2018.10.024

Liu, C., Xia, J., 2012. Detection and Attribution of Observed Changes in the Hydrological Cycle under Global Warming. Advances in Climate Change Research. 2 (1), 31-37.https://doi.org/10.3724/SP.J.1248.2011.00031

Liu, X.N., Liu, Z.D., Zhang, Y., Jiang, B.F., 2016. Quantitative analysis of burden of bacillary dysentery associated with floods in Hunan, China. Sci. Total. Environ. 547, 190-196.https://doi.org/10.1016/j.scitotenv.2015.12.160

Loperfido, J.V., Noe, G.B., Jarnagin, S.T., Hogan, D.M., 2014. Effects of distributed and centralized stormwater best management practices and land cover on urban stream hydrology 
at the catchment scale. J. Hydrol. 519,

2584-2595.https://doi.org/10.1016/j.jhydrol.2014.07.007

Mahmoud, W.H., Elagib, N.A., Gaese, H., Heinrich, J., 2014. Rainfall conditions and rainwater harvesting potential in the urban area of Khartoum. Resour.Conserv.Recy. 91, 89-99.https://doi.org/10.1016/j.resconrec.2014.07.014

Mehrabadi, M.H.R., Saghafian, B., Fashi, F.H., 2013. Assessment of residential rainwater harvesting efficiency for meeting non-potable water demands in three climate conditions. Resour.Conserv.Recy. 73, 86-93.https://doi.org/10.1016/j.resconrec.2013.01.015

Philpot, S., Hipel, K., Johnson, P., 2016. Strategic analysis of a water rights conflict in the south western United States. J. Environ. Manage. 180, 247-256.https://doi.org/10.1016/j.jenvman.2016.05.027

Pohlner, H., 2016. Institutional change and the political economy of water megaprojects: China's south-north water transfer. Global. Environ. Change. 38, 205-216.https://doi.org/10.1016/j.gloenvcha.2016.03.015

Pokorný, J., Rejšková, A., 2008. Water Cycle Management. Encyclopedia of Ecology. 3729-3737.https://doi.org/10.1016/B978-008045405-4.00081-1

Qian, Q.H., 2016. Present state, problems and development trends of urban underground space in China. Tunn.Undergr. Sp. Tech. 55, 280-289.https://doi.org/10.1016/j.tust.2015.11.007

Qian, Y., 2016. Sustainable Management of Water Resources. Engineering. 2 (1), 23-25.https://doi.org/10.1016/J.ENG.2016.01.006

Rasul, G., 2016. Managing the food, water, and energy nexus for achieving the Sustainable Development Goals in South Asia. Environmental Development. 18, 
14-25.https://doi.org/10.1016/j.envdev.2015.12.001

Shao, W.W., Zhang, H.X., Liu, J.H., Yang, G.Y., Chen, X.D., Yang, Z.Y., Huang, H., 2016. Data Integration and its Application in the Sponge City Construction of CHINA. Procedia Engineering. 154, 779-786.https://doi.org/10.1016/j.proeng.2016.07.583

Sun, Y., Tong, S., Yang, Y.J., 2016. Modeling the cost-effectiveness of stormwater best management practices in an urban watershed in Las Vegas Valley. Applied Geography. 76, 49-61.https://doi.org/10.1016/j.apgeog.2016.09.005

Tedoldi, D., Chebbo, G., Pierlot, D., Kovacs, Y., Gromaire, M.C., 2016. Impact of runoff infiltration on contaminant accumulation and transport in the soil/filter media of Sustainable Urban Drainage Systems: A literature review. Sci. Total. Environ. 569-570, 904-926.https://doi.org/10.1016/j.scitotenv.2016.04.215

Thuy, N.T., Hao, H., Guo, W.S., Wang, X.C., Ren, N.Q., Li, G.B., Ding, J., Liang, H., 2019. Implementation of a specific urban water management-Sponge City. Science of the Total Environment. 652, 147-162. http://dx.doi.org/10.1016/j.scitotenv.2018.10.168

Wang Q., Zhang Q.H.,WuYaketon, WangX.C.,2017.Physicochemical conditions and properties of particles in urban runoffand rivers: Implications for runoff pollution.Chemosphere 173 () 318-325.http://dx.doi.org/10.1016/j.chemosphere.2017.01.066

Wang, X.C., Zhan, C.M., Ma, X.Y., Luo, L., 2015. Water Cycle Management A New Paradigm of Wastewater Reuse and Safety Control. springer. http://dx.doi.org/10.1007/978-3-662-45821-1

Yan, B.W., Chen, L., 2013. Coincidence probability of precipitation for the middle route of South-to-North water transfer project in China. J.Hydrol. 499, 19-26. https://doi.org/10.1016/j.jhydrol.2013.06.040 
Yan, D., Yao, M.T., Ludwig, F., Kabat, P., Huang, H.Q., Hutjes, R.W.A., Werners, S.E., 2018. Exploring future water shortage for large river basins under different water allocation strategies. Water Resour Manage. 32, 3071-3086.https://doi.org/10.1007/s11269-018-1975-8

Zhang, Q.H., Wang, W.H., Ngo, H.H., Guo, W.S., Jin, P.K., Dzakpasu, M., Yang, S.J., Wang, Q., Wang, X.C., Ao, D., 2016. Current status of urban wastewater treatment plants in China. Environ. Int. 92-93, 11-22.https://doi.org/10.1016/j.envint.2016.03.024

Zhao, Z.Y., Zuo, J., Zillante, G., 2015. Transformation of water resource management: a case study of the South-to-North Water Diversion project. J. Clean. Prod. http://dx.doi.org/10.1016/j.jclepro.2015.08.066.

Zhuang, W., Ying, S.C., Frie,A.L., Wang, Q., Song, J.M., Liu, Y.X., Chen, Q., Lai, X.Y., 2019. Distribution, pollution status, and source apportionment of trace metals in lake sediments under the influence of the South-to-North Water Transfer Project, China. Science of the Total Environment. 671, 108-118. http://dx.doi.org/10.1016/j.scitotenv.2019.03.306 